\title{
PENGEMBANGAN SISTEM PENJAMINAN MUTU SEKOLAH BERBASIS DIGITAL DI SMA NEGERI 2 TEBING TINGGI
}

\author{
Isda Pramuniati ${ }^{*}$, Arnita ${ }^{2}$, Insan Taufik ${ }^{3}$ \\ Jurusan Bahasa Asing Fakultas Bahasa dan Seni, Jurusan Matematika Fakultas Matematika dan \\ Ilmu Pengetahuan Alam Universitas Negeri Medan, Medan, Indonesia \\ *Penulis Korespondensi : isda@unimed.ac.id
}

\begin{abstract}
ABSTRAK
Penjaminan dan peningkatan mutu pendidikan tidak lepas kaitannya dengan manajemen mutu. Berkaitan dengan itu perlu adanya upaya pengendalian mutu (quality control) secara berkelanjutan. Lemahnya komitmen kepala sekolah, guru, tenaga pendidikan dalam melaksanakan sistem penjaminan mutu, serta keterbatasan jumlah kompetensi SDM dalam pemahaman SPMI di SMA Negeri 2 Tebing Tinggi membuat sistem penjaminan mutu sekolah tidak berjalan dengan maksimal. Kegiatan Pengabdian kepada Masyaraat (PkM) ini bertujuan memberikan pendampingan dan sosialisasi sistem penjaminan mutu pendidikan mengikuti siklus SPMI yang disempurnakan berbasis digital untuk memastikan pelaksanaan SPMI berjalan dengan terus menerus dan berkelanjutan di SMA Negeri 2 Tebing Tinggi serta melakukan pemetaan mutu untuk membangun sistem pengawasan sekolah. Kegiatan PkM Pengembangan Sistem Penjaminan Mutu Sekolah Berbasis Digital dimulai dengan melakukan pemetaan mutu berdasarkan Standar Nasional Pendidikan (SNP), pembuatan Rencana Kerja Sekolah (RKS), pemenuhan mutu baik dalam pengolahan SNP pada proses pembelajaran, monitoring dan evaluasi pelaksanaan, penetapan standar baru, evaluasi hasil implementasi, dan pembuatan sistem penjaminan mutu sekolah berbasis digital. Kegiatan ini menghasilkan luaran berupa sistem penjaminan mutu sekolah berbasis digital yang memuat standar mutu, prosedur operasional baku, kurikulum, RKS, data siswa, guru, prestasi siswa, serta prestasi guru.
\end{abstract}

\section{Kata Kunci : Digital; Penjaminan Mutu; Sistem}

\begin{abstract}
Guarantee and improving the quality of education is closely related to quality management. Associated with it is necessary to encourage quality control (quality control) in a sustainable manner. The weak commitment of head master, teachers and education personnel in implementing the quality assurance system, as well as the limited number of human resource competencies in understanding SPMI at SMA Negeri 2 Tebing Tinggi make the school quality assurance system not running optimally. This community service activities (PkM) aims to provide assistance and socialization of the education quality assurance system following the SPMI cycle which is enhanced with a digital-based system to ensure that the implementation of SPMI runs continuously and sustainably in SMA Negeri 2 Tebing Tinggi and conducts quality mapping to build a school supervision system. Development of a Digital-Based School Quality Assurance System begins with quality mapping based on Nastional Education Standars (SNP), preparation of School Work Plans (RKS), quality fulfillment in both SNP processing and learning processes, monitoring and evaluation of implementation, setting new standards, evaluating implementation results, and creating a guarantee system digital-based school quality. The results of this activity resulted in a digital-based school quality assurance system containing quality standards, standard operational procedures, curriculum, RKS, student data, teacher data, student achievement data, and teacher achievement data.
\end{abstract}

Keywords : Digital; Quality Assurance; Systems 


\section{PENDAHULAN}

SMA Negeri 2 Tebing Tinggi adalah salah satu SMA unggulan yang ada di kota Tebing Tinggi. Sekolah ini terletak di jalan K.L. Yos Sudarso Km. 5 Kelurahan Rantau Laban Kecamatan Rambutan. Tercatat 46 orang guru tetap yang dimiliki sekolah. Banyak prestasi yang sudah ditorehkan oleh siswasiswi SMA Negeri 2 Tebing Tinggi yang mengakibatkan daya saing untuk masuk cukup tinggi di sekolah tersebut. Berbagai upaya dilakukan SMA Negeri 2 Tebing Tinggi untuk menjaga mutu sekolah. Namun hampir sama dengan pada umumnya sekolah, beberapa kendala yang berkaitan dengan penjaminan mutu sekolah sering dihadapi. Berdasarkan hasil wawancara dengan Bapak Paino selaku Kepala Sekolah SMA Negeri 2 Tebing Tinggi, beberapa kendala yang ditemui dalam implementasi penjaminan mutu sekolah antara lain: (1) Lemahnya komitmen pelaksana pendidikan dalam hal ini kepala sekoah, guru dan tenaga kependidikan dalam melaksanakan Sistem Penjaminan Mutu Internal (SPMI); (2) Keterbatasan jumlah dan kompetensi SDM sekolah yang paham tentang SPMI secara utuh dan benar. (3) Budaya penolakan (resistance) yang kuat terhadap setiap perubahan, termasuk perubahan ke arah perbaikan mutu; (4) sikap dan pendapat bahwa tanggungjawab untuk menjamin, meningkatkan, dan membudidayakan mutu hanya terletak pada pimpinan bukan pada setiap individu yang terlibat dalam penyelenggara pendidikan.

Padahal dalam implementasinya, sistem penjaminan mutu pendidikan harus mengikuti siklus kegiatan sesuai dengan komponen masing masing. Di mana siklus sistem penjaminan mutu internal terdiri atas:

1. Pemetaan mutu pendidikan yang dilaksanakan oleh satuan pendidikan berdasarkan Standar Nasional Pendidikan;

2. Pembuatan rencana peningkatan mutu yang dituangkan dalam Rencana Kerja Sekolah;

3. Pelaksanaan pemenuhan mutu baik dalam pengelolaan satuan pendidikan maupun proses pembelajaran;

4. Monitoring dan evaluasi proses pelaksanaan pemenuhan mutu yang telah dilakukan;

5. Penetapan standar baru dan penyusunan strategi peningkatan mutu berdasarkan hasil monitoring dan evaluasi.

Oleh karena itu perlu dilakukan Sistem Penjaminan Mutu Pendidikan yang merupakan suatu kesatuan unsur yang terdiri atas organisasi, kebijakan, dan proses terpadu yang mengatur segala kegiatan untuk meningkatkan mutu pendidikan secara sistematis, terencana dan berkelanjutan.

\section{METODE PELAKSANAAN}

Metode pelaksanaan kegiatan ini diimplementasikan melalui tahapan sosialisasi, pendampingan dan evaluasi, yaitu sebagai berikut:
1. Pemetaan mutu pendidikan yang dilaksanakan oleh satuan pendidikan berdasarkan Standar Nasional Pendidikan;

2. Pembuatan rencana peningkatan mutu yang dituangkan dalam Rencana Kerja Sekolah;

3. Pelaksanaan pemenuhan mutu baik dalam pengelolaan satuan pendidikan maupun proses pembelajaran;

4. Monitoring dan evaluasi proses pelaksanaan pemenuhan mutu yang telah dilakukan;

5. Penetapan standar baru dan penyusunan strategi peningkatan mutu berdasarkan hasil monitoring dan evaluasi;

6. Evaluasi terhadap hasil implementasi sistem penjaminan mutu berbasis digial pada lokasi mitra;

7. Menghasilkan sistem penjaminan mutu sekolah berbasis digital di SMA Negeri 2 Tebing Tinggi.

Selain itu terdapat pula pendekatan yang dilakukan dalam berjalannya proses pendampingan sebagai berikut:

1. Memberikan penjelasan kepada pimpinan dan pelaksana sistem penjaminan mutu yang ada lokasi mitra mengenai pentingnya sistem penjaminan mutu berbasis digital;

2. Melakukan observasi dan wawancara mengenai bagaimana keberlangsungan sistem penjaminan mutu yang ada di lokasi mitra;

3. Memberikan masukan terhadap hal-hal yang mungkin perlu ditambahakan atau diperbaiki dari berjalannya sistem penjaminan mutu di lokasi mitra;

4. Menjelaskan sistematika rancangan sistem penjaminan mutu yang akan diintergrasikan dengan mengunakan teknologi digital serta kemudahan yang ditawarkan.

5. Mendampingin mitra dalam menjalankan sistem penjaminan mutu berbasis digital serta dengan sebelumnya memberikan pelatihan-pelatihan guna menunjang terlaksananya sistem penjaminan mutu berbasis digital dengan baik.

\section{HASIL DAN PEMBAHASAN}

Seluruh rangkaian kegiatan melibatkan tim dan partisipasi dari mitra pelaksana program. Adapun rangkaian kegiatan tersebut, yaitu:

\begin{tabular}{|c|l|l|l|}
\hline No & \multicolumn{1}{|c|}{ Kegiatan } & \multicolumn{1}{|c|}{ Target } & \multicolumn{1}{|c|}{$\begin{array}{c}\text { Keterlibatan } \\
\text { Mitra }\end{array}$} \\
\hline 1 & $\begin{array}{l}\text { Melakukan } \\
\text { diskusi serta } \\
\text { pembukaan } \\
\text { tentang } \\
\text { sistem } \\
\text { penjaminan } \\
\text { mutu sekolah } \\
\text { berbasis } \\
\text { digital }\end{array}$ & $\begin{array}{l}\text { Pemahaman } \\
\text { pimpinan dan } \\
\text { fungsionaris } \\
\text { sistem } \\
\text { penjamian } \\
\text { mutu }\end{array}$ & $\begin{array}{l}\text { Menyediakan } \\
\text { ruangan dan } \\
\text { mengikuti } \\
\text { acara serta } \\
\text { paparan sistem } \\
\text { penjaminan } \\
\text { mutu yang } \\
\text { sedang berjalan }\end{array}$ \\
& & & \\
& & & \\
\hline
\end{tabular}




\begin{tabular}{|c|c|c|c|}
\hline No & Kegiatan & Target & $\begin{array}{c}\text { Keterlibatan } \\
\text { Mitra }\end{array}$ \\
\hline 2 & $\begin{array}{l}\text { Melakukan } \\
\text { diskusi } \\
\text { tentang } \\
\text { sistem } \\
\text { penjaminan } \\
\text { mutu } \\
\text { berbasis } \\
\text { digital yang } \\
\text { akan } \\
\text { diterapkan }\end{array}$ & $\begin{array}{l}\text { Menggali } \\
\text { kecocokan } \\
\text { antara sistem } \\
\text { yang } \\
\text { ditawarkan } \\
\text { dengan } \\
\text { sistem yang } \\
\text { dibutuhkan } \\
\text { oleh mitra }\end{array}$ & $\begin{array}{l}\text { Menyediakan } \\
\text { ruangan dan } \\
\text { mengikuti } \\
\text { kegiatan }\end{array}$ \\
\hline 3 & $\begin{array}{l}\text { Percobaan } \\
\text { sistem } \\
\text { penjaminan } \\
\text { mutu } \\
\text { berbasis } \\
\text { digital }\end{array}$ & $\begin{array}{l}\text { Respon mitra } \\
\text { terhadap } \\
\text { sistem yang } \\
\text { ditawarkan }\end{array}$ & $\begin{array}{l}\text { Meneyediakan } \\
\text { tempat dan } \\
\text { memberikan } \\
\text { feedback }\end{array}$ \\
\hline 4 & $\begin{array}{l}\text { Melakukan } \\
\text { perbaikan } \\
\text { dan } \\
\text { melakukan } \\
\text { percobaan } \\
\text { ulang }\end{array}$ & $\begin{array}{l}\text { Respon mitra } \\
\text { terhadap } \\
\text { sistem, } \\
\text { apakah sudah } \\
\text { sesuai dengan } \\
\text { kondisi mitra }\end{array}$ & $\begin{array}{l}\text { Menyediakan } \\
\text { tempat dan } \\
\text { memeberikan } \\
\text { feedback }\end{array}$ \\
\hline 5 & $\begin{array}{l}\text { Implementasi } \\
\text { dan } \\
\text { memberikan } \\
\text { pelatihan } \\
\text { sistem } \\
\text { penjaminan } \\
\text { mutu } \\
\text { berbasis } \\
\text { digital }\end{array}$ & $\begin{array}{l}\text { Kesalahan } \\
\text { sistem, } \\
\text { debug, error } \\
\text { dan } \\
\text { malfungsi } \\
\text { terhadap } \\
\text { sistem }\end{array}$ & $\begin{array}{l}\text { Menyediakan } \\
\text { server hosting } \\
\text { dan } \\
\text { menjalankan } \\
\text { sistem }\end{array}$ \\
\hline 6 & $\begin{array}{l}\text { Evalusi } \\
\text { terhadap } \\
\text { sistem } \\
\text { penjaminan } \\
\text { mutu } \\
\text { berbasis } \\
\text { digital }\end{array}$ & $\begin{array}{l}\text { Hal-hal yang } \\
\text { perlu } \\
\text { ditingkatkan } \\
\text { atau di } \\
\text { perbaiki } \\
\text { dimasa } \\
\text { mendatang }\end{array}$ & $\begin{array}{l}\text { Meyediakan } \\
\text { tempat dan } \\
\text { mengikuti } \\
\text { kegiatan }\end{array}$ \\
\hline
\end{tabular}

Berdasarkan hasil pemetaan mutu pendidikan yang dilaksanakan diketahui bahwa SMAN memiliki sasaran mutu sebagai berikut :

1. Tingkat Kelulusan UN ( Ujian Nasional) $=100 \%$

2. Jumlah siswa yang meperoleh nilai UN bahasa Inggris $=7,80$ mencapai $=81 \%$

3. Jumlah siswa yang meperoleh nilai UN bahasa Indonesia $=7,00$ mencapai $=80 \%$

4. Jumlah siswa yang meperoleh nilai UN Matematika $=7,80$ mencapai $=86 \%$

5. Tingkat kelulusan $100 \%$ dengan rata-rata $=8,75$

6. Tingkat kehadiran guru pada saat mengajar $=$ $100 \%$

7. Tingkat kehadiran siswa mencapai $=97 \%$

8. Tingkat keterlambatan siswa masuk sekolah $=$ $5 \%$

9. Tingkat pelanggaran tata tertib siswa $=2 \%$

10. Juara I Lomba Kompetensi Siswa Tingkat Propinsi mencapai 4 (enam) cabang lomba
11. Terjalin partner tingkat nasional satu institusi

12. Pembenahan manajemen sekolah untuk mencapai Sertifikat ISO 9001-2008

Untuk dapat memenuhi kebutuhan pemetaan mutu berdasarkan pencapaian sasaran mutu makan tim PkM membantu dan memberi pendampingan SMAN 2 tebing Tinggi menjaring data untuk menghasilkan raport mutu melalui aplikasi sistem digital penjaminan mutu. Melalui aplikasi ini diharapkan pihak sekolah dapat memantau ketercapaian sasaran mutu melalui data yang diperoleh melalui aplikasi.

Berikut ini adalah tampilan aplikasi sistem penjaminan mutu pendidikan di SMAN 2 Tebing Tinggi.

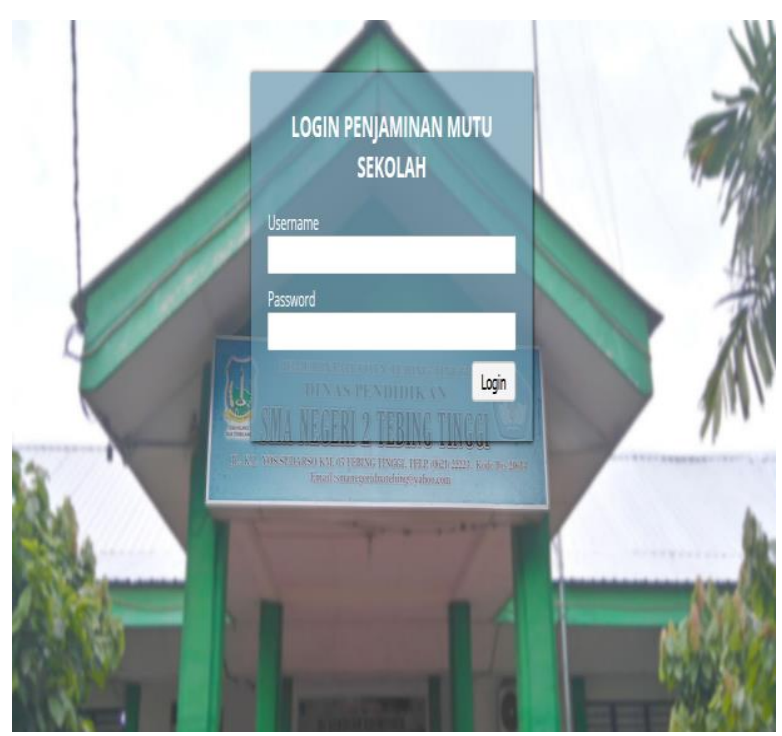

Gambar 1. Halaman Muka

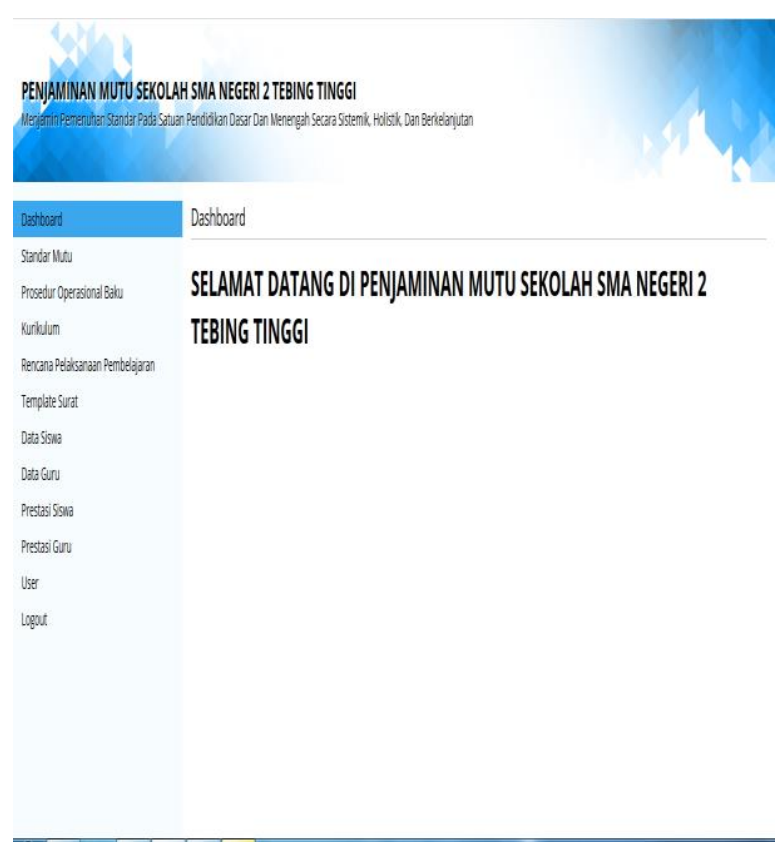


Gambar 2. Tampilan Dashboard

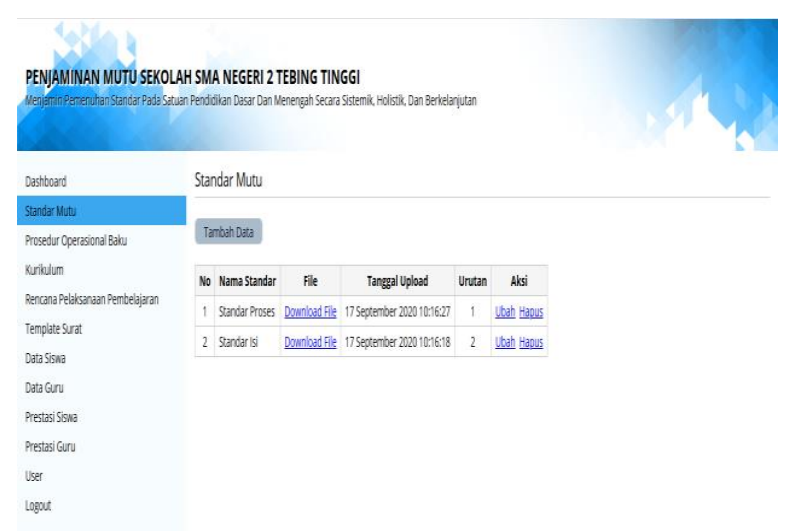

Gambar 3. Tampilan Menu

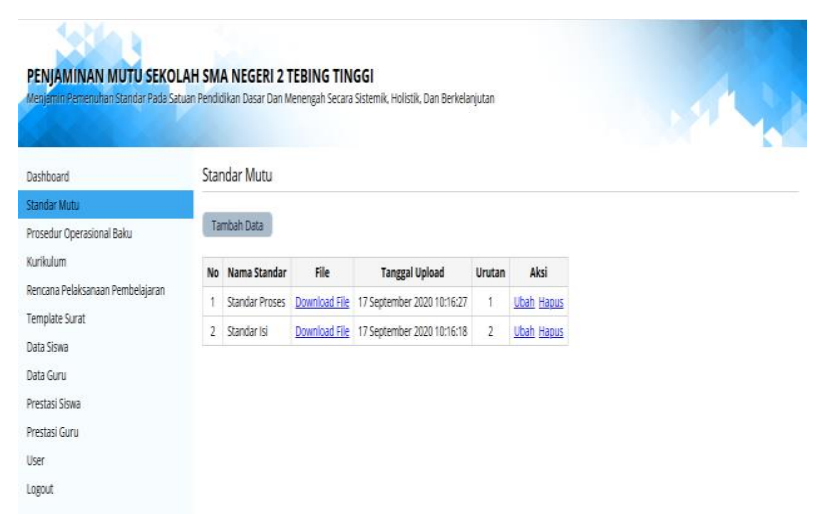

Gambar 4. Tampilan form pengisian data

Setelah rangkaian pelaksanaan Pengabdian kepada Masyarakat (PkM) dilaksanakan, maka dilakukan evaluasi dengan cara menyebarkan angket kepada peserta untuk mengetahui tingkat kepuasna peserta. Angket kepuasan terdiri dari 3 indikator penialaian diantaranya adalah materi, instruktur dan metode pelatihan. Secara umum hasil dari analisis angket yang sudah disebar peserta merasa puas dengan kegiatan PkM yang sudah dilaksanakan. Materi yang disampaikan dapat dengan mudah diterima oleh peserta, instruktur juga melakukan pendampingan dengan baik sehingga peserta mampu mengembangkan aplikasi dan updating data, metode pelatihan juga sangat menyenangkan.

\section{KESIMPULAN}

Kegiatan pengembangan sistem penjaminan mutu sekolah di SMA Negeri 2 Tebing Tinggi menghasilkan sistem penjaminan mutu sekolah berbasis digital yang memuat standar mutu, prosedur operasional baku, kurikulum, RKS, data siswa, guru, prestasi siswa, serta prestasi guru. Dengan adanya aplikasi ini, sekolah dapat menginventaris data terkait rapor sekolah. Hal ini diperlukan sebagai pencataan rekam jejak dan branding sekolah, sehingga SMAN 2 Tebing Tinggi dapat mencapai Visi dan Misi sekolah "Bertaqwa, Berprestasi, Berbudaya yang Berwawasan Lingkungan".

Evaluasi terhadap kegiatan $\mathrm{PkM}$ yang sudah dilakukan diukur dengan cara meyebarkan angket kepuasan peserta terhadap pelaksanaan kegiatan. Angket terdiri dari 3 indikator diataranya materi, instruktur dan metode pelaksanaan. Secara umum peserta puas dengan kegiatan yang sudah dilaksanakan. Materi yang disampaikan dapat dengan mudah diterima oleh peserta, instruktur juga melakukan pendampingan dengan baik sehingga peserta mampu mengembangkan aplikasi dan updating data, metode pelatihan juga sangat menyenangkan.

\section{REFERENSI}

Barry, Render dan Jay Heizer. 2001. Prinsip-prinsip Manajemen Operasi: Operations Management. Jakarta: Salemba Empat.

Feigenbaum, A. V., (1986), Total Quality Control, Third Edition, McGrow-Hill Book Company, New York

Hanief Saha Ghafur, dkk. 2011. Arsitektur Organisasi Penjaminan Mutu Pendidikan Nasional: Sebuah Konstruksi Untuk Model Aplikasi. (Hasil

Kurniawan, D. 2014. URGENSI PENJAMINAN MUTU SEKOLAH. Jurnal Edutech, Tahun 13, Vol.1, No.2, Juni 2014

Peraturan Menteri Pendidikan Nasional Nomor 63/2009 tentang Sistem Penjaminan dan Peningkatan Mutu Pendidikan.

Peraturan Pemerintah Republik Indonesia Nomor 19/2005 tentang Standar Nasional Pendidikan.

Peraturan Pemerintah Republik Indonesia Nomor 32/2013 tentang Standar Nasional Pendidikan. Utama.

Sastrawan, K. B. 2019. Peningkatan Mutu Pendidikan

Melalui Perencanaan Mutu Strategis. Jurnal Penjaminan Mutu Lembaga Penjaminan Mutu Volume 5 Nomor 2 Agustus 2019 ISSN : 2407912x (Cetak) Institut Hindu Dharma Negeri ISSN : 2548-3110 (Online) DENPASAR

Sugiyono, 2011. Metode Penelitian Kuantitatif, Kualitatif dan R\&D. Jakarta: Alfhabeta.

Soetopo, H. 2009. Manajemen Berbasis Sekolah dan Kurikulum Berbasis Kompetensi (Bunga Rampai Pokok Pikiran Pembaharuan Pendidikan di Indonesia). Malang: FIP UM.

Undang-undang Nomor 20/2003 tentang Sistem Pendidikan Nasional. 
Undang-undang Nomor 23/ 2014 tentang Pemerintah Daerah. 